case supports an aggressive surgical approach for these often critically ill patients.

\footnotetext{
References

1. Lang RM, Bierig M, Devereux RB, Flachskampf FA, Foster E, Pellikka PA, et al. Recommendations for chamber quantification: a report from the American Society of Echocardiography's Guidelines and Standards Committee and the Chamber Quantification Writing Group, developed in conjunction with the European Association of Echocardiography, a branch of the European Society of Cardiology. $J$ Am Soc Echocardiogr. 2005;18:1440-63.
}

2. Hayashi J, Okazaki H, Nakazawa S, Watanabe H, Miyamura H, Eguchi S. Right ventricular systolic performance before and after surgery for tricuspid regurgitation associated with mitral stenosis. Jpn Circ J. 1996;60:96-101.

3. Filsoufi F, Anyanwu C, Salzberg SP, Frankel T, Cohn LH, Adams DH. Long-term outcomes of tricuspid valve replacement in the current era. Ann Thorac Surg. 2005; 80:845-50.

4. Moraca RJ, Moon MR, Lawton JS, Guthrie TJ, Aubuchon KA, Moazami N, et al. Outcomes of tricuspid valve repair and replacement: a propensity analysis. Ann Thorac Surg. 2009;87:83-9.

5. Péterffy A, Jonasson R, Henze A. Hemodynamic changes after tricuspid valve surgery. A recatheterization study in forty-five patients. Scand J Thorac Cardiovasc Surg. 1981;15:161-70.

\title{
Overcoming challenges: The use of minimal extracorporeal circulation in Jehovah's Witnesses undergoing cardiac surgery
}

\author{
Anil John, FRCS, Mark Bennett, MD, FRCA, Clinton Lloyd, FRCS (CTh), and Simon Allen, FRCS (CTh), \\ Plymouth, United Kingdom
}

Cardiac surgery in Jehovah's Witnesses often poses a challenge to the surgeon because these patients refuse transfusion of the primary components of blood (red cells, white cells, plasma, and platelets), although individual believers can decide for themselves to accept processed fractions of the primary components. Most cardiac surgeons around the world use standard cardiopulmonary bypass circuits for coronary artery bypass grafting in these patients. Minimal extracorporeal circulation (MECC) is a fully heparin-coated closed-loop cardiopulmonary bypass system. It excludes the blood-gas interface and has active venous drainage, a centrifugal pump, membrane oxygenator, and a priming volume of $800 \mathrm{~mL}$, reduced further to around $300 \mathrm{~mL}$ by the use of retrograde priming of the circuit.

\section{CLINICAL SUMMARY}

Between May 2007 and February 2009, 7 Jehovah Witness patients underwent cardiac surgery using this technique (coronary artery bypass grafting in 6 and aortic valve replacement in 1). There were 6 male patients and 1 female patient with an average age of 63 years. Comorbidites included hypertension, and 1 patient had poor left ventricular function (Table I).

\footnotetext{
From the Southwest Cardiothoracic Centre, Cardiothoracic Surgery, Derriford Hospital, Plymouth, United Kingdom.

Disclosures: None.

Received for publication July 12, 2009; revisions received Aug 26, 2009; accepted for publication Sept 16, 2009; available ahead of print Nov 20, 2009.

Address for reprints: Anil John, FRCS, Southwest Cardiothoracic Centre, Department of Cardiothoracic Surgery, Derriford Hospital, Plymouth PL6 8DH, United Kingdom (E-mail: ajohn234@hotmail.com).

J Thorac Cardiovasc Surg 2010;139:e122-3

$0022-5223 / \$ 36.00$

Copyright (c) 2010 by The American Association for Thoracic Surgery doi:10.1016/j.jtcvs.2009.09.024
}

Average preoperative hemoglobin level was $14 \pm 2.01$ $\mathrm{g} / \mathrm{dL}$; postoperative hemoglobin level $10.35 \pm 1.32 \mathrm{~g} / \mathrm{dL}$ and percentage drop of hemoglobin on day 1 was $25 \% \pm$ $9.04 \%$. Average bypass time was $53 \pm 8.57$ minutes.

\section{DISCUSSION}

Standard cardiopulmonary bypass circuits are associated with marked hemodilution in addition to initiation of the inflammatory response because of contact between blood and artificial surfaces on the lines and oxygenator and also at the

TABLE 1. Patient characteristics

\begin{tabular}{|c|c|c|c|c|c|c|c|}
\hline & \multicolumn{7}{|c|}{ Patient no. } \\
\hline & 1 & 2 & 3 & 4 & 5 & 6 & 7 \\
\hline Age $(y)$ & 65 & 71 & 71 & 50 & 64 & 50 & 72 \\
\hline Sex & $\mathrm{M}$ & M & $\mathrm{M}$ & M & $\mathrm{M}$ & $\mathrm{M}$ & $\mathrm{F}$ \\
\hline Hypertension & No & Yes & Yes & Yes & No & Yes & No \\
\hline LV function & Good & Good & Poor & Good & Good & Good & Good \\
\hline Surgery & CABG & $\mathrm{CABG}$ & $\mathrm{CABG}$ & CABG & $\mathrm{CABG}$ & $\mathrm{CABG}$ & AVR \\
\hline No. of grafts & 3 & 3 & 3 & 2 & 3 & 2 & None \\
\hline Preop Hb (g/dL) & 14.8 & 14 & 9.7 & 13.9 & 15.6 & 15.6 & 14.2 \\
\hline Crossclamp (min) & 30 & 34 & 36 & 23 & 27 & 25 & 37 \\
\hline Bypass time (min) & 51 & 62 & 57 & 36 & 60 & 52 & 52 \\
\hline Postop $\mathrm{Hb}(\mathrm{g} / \mathrm{dL})$ & 12.2 & 10.4 & 8.2 & 11.7 & 9.6 & 10.3 & 10.1 \\
\hline Drop in $\mathrm{Hb}(\%)$ & 18 & 26 & 15 & 16 & 38 & 34 & 28 \\
\hline Day $4 \mathrm{Hb}(\mathrm{g} / \mathrm{dL})$ & 14.2 & 11.4 & 8.7 & 11.4 & 11.3 & 11.2 & 10 \\
\hline Total blood loss (mL) & 540 & 470 & 865 & 380 & 420 & 310 & 440 \\
\hline Extubation time (h) & 2.5 & 4 & 2.5 & 2 & 2 & 2 & 3 \\
\hline ITU stay $(\mathrm{d})$ & 1 & 1 & 2 & 2 & 1 & 1 & 1 \\
\hline $\begin{array}{l}\text { Length of stay } \\
\text { in hospital (d) }\end{array}$ & 6 & 7 & 14 & 6 & 6 & 6 & 6 \\
\hline
\end{tabular}


blood-air interface. ${ }^{1}$ Inasmuch as this response affects coagulation, it probably contributes to the perioperative fall in hemoglobin. ${ }^{2}$

The MECC circuit has a very short tubing length with elimination of the venous reservoir and avoids the conventional cardiotomy suction. As a result, there is a lower priming volume and reduced hemodilution compared with conventional cardiopulmonary circuits ${ }^{3}$ and probably less initiation of the inflammatory response.

Patients undergoing bypass surgery on MECC systems have 30-day mortalities comparable with those of patients treated with conventional bypass circuits. ${ }^{4}$ Studies have also repeatedly demonstrated a decreased requirement for blood transfusions. ${ }^{4}$ In our patients, the postoperative hemoglobin concentration remained higher than our standard transfusion trigger $(8.0 \mathrm{~g} / \mathrm{dL})$ and was consistent with previous studies ${ }^{4,5}$ (Table 1). MECC also allows for complete revascularization on a still heart and bloodless field and in our experience is technically less demanding than off-pump surgery.

The reduced priming volume of the MECC system results in less hemodilution and maintains a near normal hematocrit during the CPB process. This technique contributes significantly to the avoidance of blood transfusion in this subgroup of patients. We have successfully used this technique in our institution for coronary artery bypass surgery and more recently for aortic valve surgery, and we consider the MECC procedure a useful tool in the armamentarium for Jehovah's Witnesses undergoing cardiac surgery. As the evidence for the adverse consequences of homologous blood transfusion mounts, we should consider treating all of our patients with fully heparin-coated circuits, low priming volumes, and meticulous surgical hemostasis as in our Jehovah Witness patients.

We are grateful to Gerry Webb for his assistance in the study.

\section{References}

1. Aldea GS, Soltow LO, Chandler WL, Triggs CM, Vocelka CR, Crockett GI, et al. Limitation of thrombin generation, platelet activation, and inflammation by elimination of cardiotomy suction in patients undergoing coronary artery bypass grafting treated with heparin-bonded circuits. J Thorac Cardiovasc Surg. 2002;123: 742-55.

2. Royston D. The inflammatory response and extracorporeal circulation. J Cardio thorac Vasc Anesth. 1997;11:341-54.

3. Fromes Y, Gaillard D, Ponzio O, Chauffert M, Gerhardt MF, Deleuze P, et al Reduction of the inflammatory response following coronary bypass grafting with total minimal extracorporeal circulation. Eur J Cardiothorac Surg. 2002;22: 527-33.

4. Remadi JP, Rakotoarivelo Z, Marticho P, Benamar A. Prospective randomized study comparing coronary artery bypass grafting with the new mini-extracorporeal circulation Jostra system or with a standard cardiopulmonary bypass. Am Heart J. 2006;151:198.

5. Mueller XM, Jegger D, Augstburger M, Horisberger J, Godar G, von Segesser LK A new concept of integrated cardiopulmonary bypass circuit. Eur J Cardiothorac Surg. 2002;21:840-6.

\title{
Use of the hybrid operating room for aortic valve replacement in a patient with anomalous left circumflex artery
}

\author{
Ramanan Umakanthan, MD, Zachary E. Brewer, BS, John G. Byrne, MD, and Rashid M. Ahmad, MD, \\ Nashville, Tenn
}

Preoperative detection of anomalous coronary artery anatomy and clear delineation of its anatomic course are essential in patients undergoing aortic valve surgery so that the surgical technique can be modified to avoid coronary vessel injury. We present the case of aortic valve replacement (AVR) in a patient who was discovered to have an aberrant left circumflex artery (LCX) on coronary angiographic

\footnotetext{
From the Vanderbilt Heart \& Vascular Institute, Nashville, Tenn

Disclosures: None.

Received for publication April 2, 2009; revisions received April 22, 2009; accepted for publication April 30, 2009; available ahead of print July 6, 2009.

Address for reprints: Rashid M. Ahmad, MD, Vanderbilt Heart \& Vascular Institute,

1215 21st Ave South, Nashville, TN 37232-8802 (E-mail: rashid.ahmad@

vanderbilt.edu)

J Thorac Cardiovasc Surg 2010;139:e123-5

$0022-5223 / \$ 36.00$

Copyright (C) 2010 by The American Association for Thoracic Surgery

doi:10.1016/j.jtcvs.2009.04.048
}

analysis. We present a new surgical approach for AVR in the setting of an anomalous LCX.

\section{CLINICAL SUMMARY}

A 51-year-old man with a history of aortic stenosis, progressively worsening dyspnea, and an abnormal stress test result was referred to the Vanderbilt Heart Institute for AVR. Transesophageal echocardiographic analysis had revealed an aortic valve area of $0.75 \mathrm{~cm}^{2}$ and an ejection fraction of $65 \%$ to $70 \%$. Preoperative coronary angiographic analysis revealed no significant atherosclerotic disease but demonstrated an anomalous LCX that originated from a separate ostium adjacent to the ostium of the right coronary artery and coursed behind the aortic annulus. Computed tomographic angiographic analysis confirmed the retroaortic course of the LCX. 